\title{
Molecular cloning and nucleotide sequence of the gene encoding an endo-1,4- $\beta$-glucanase from Bacillus sp. KSM-330
}

\author{
Katsuya Ozaki, ${ }^{*}$ Nobuyuki Sumitomo and Susumu Ito \\ Tochigi Research Laboratories of Kao Corporation, 2606 Akabane, Ichikai, Haga, Tochigi 321-34, Japan
}

(Received 14 May 1991; revised 11 July 1991; accepted 22 July 1991)

\begin{abstract}
The gene encoding an acid endo-1,4- $\beta$-glucanase from Bacillus sp. KSM-330 was cloned into the HindIII site of pBR322 and expressed in Escherichia coli HB101. The recombinant plasmid contained a $3.1 \mathrm{~kb}$ HindIII insert, $1.8 \mathrm{~kb}$ of which was sufficient for the expression of endoglucanase activity in $E$. coli $\mathrm{HB101}$. Nucleotide sequencing of this region ( $1816 \mathrm{bp}$ ) revealed an open reading frame of $1389 \mathrm{bp}$. The protein deduced from this sequence was composed of 463 amino acids with an $M_{\mathrm{r}}$ of 51882 . The deduced amino acid sequence from amino acids 56 through 75 coincided with the amino-terminal sequence of the endoglucanase, Endo-K, purified from culture of Bacillus sp. KSM-330. The deduced amino acid sequence of Endo-K had $30 \%$ homology with that of the celA enzyme from Clostridium thermocellum NCIB 10682 and $25 \%$ homology with that of the enzyme from Cellulomonas uda CB4. However, the Endo-K protein exhibited no homology with respect to either the nucleotide or the amino acid sequences of other endoglucanases from Bacillus that had been previously characterized. These results indicate that the gene for Endo-K in Bacillus Sp. KSM-330 has evolved from an ancestral gene distinct from that of other Bacillus endoglucanases.
\end{abstract}

\section{Introduction}

Cellulolytic enzymes have been reported in several strains of Bacillus (Tewari \& Chahal, 1977; Dhillon et al., 1985; Fukumori et al., 1986a, b; MacKay et al., 1986; Nakamura et al., 1987; Robson \& Chambliss, 1987; Au \& Chan, 1987; Baird et al., 1990). However, cellulases from Bacillus have received very limited attention, probably because most of these enzymes hydrolyse carboxymethylcellulose (CMC) but barely hydrolyse crystalline forms of cellulose and because they have had no commercial applications until recently.

We have isolated some strains of Bacillus that produce alkaline endo-1,4- $\beta$-glucanase (EC 3.2.1.4), the properties of which fulfil the essential requirements for enzymes to be used in laundry detergents (Okoshi et al., 1990; Shikata et al., 1990; Yoshimatsu et al., 1990). A mutant strain of one of these isolates, Bacillus sp. KSM635 , is currently exploited for the industrial production of an alkaline endoglucanase for use in such detergents

Abbreviation: CMC, carboxymethylcellulose.

The nucleotide sequence data reported in this paper have been submitted to GenBank and have been assigned the accession number M68872.
(Yoshimatsu et al., 1990). We have cloned and sequenced the gene for the endoglucanase from Bacillus sp. KSM635 (Ozaki et al., 1990). The deduced amino acid sequence of the alkaline endoglucanase protein exhibited significant homology to the animo acid sequences of other alkaline (Fukumori et al., 1986a,b) and neutral (MacKay et al., 1986; Nakamura et al., 1987; Robson \& Chambliss, 1987; Zappe et al., 1988) endoglucanases produced by strains of Bacillus and by Clostridium acetobutylicum, with some amino acid residues conserved in either the alkaline enzymes or the neutral enzymes, or in both types of enzyme.

In order to clarify the mechanism of action of endo$1,4-\beta$-glucanases, with a special focus on differences in pH optima, we have purified and characterized an acid endo-1,4- $\beta$-glucanase, Endo-K, produced by Bacillus sp. KSM-330 (Ozaki \& Ito, 1991). Endo-K is active over an extremely narrow range of $\mathrm{pH}$ values, between 4.5 and $6 \cdot 5$, with an optimum $\mathrm{pH}$ at $5 \cdot 2$. One or more tryptophan residues in the enzyme molecule appear to be necessary for the expression of the endoglucanase activity. This report describes the cloning and sequencing of the gene encoding Endo-K to clarify the structure of the enzyme and to allow comparisons to be made between it and other alkaline or neutral endoglucanases. 


\section{Methods}

Bacterial strains and cloning vectors. Bacillus sp. KSM-330 was used as the source of the gene for Endo-K. This micro-organism, a relative of Bacillus subtilis, was isolated from a soil sample (Ozaki \& Ito, 1991). Escherichia coli $\mathrm{HB} 101$ ( $\mathrm{F}^{-}$hsdS20 recA13 ara-14 proA2 lacY1 galK2 rpsL20 xyl-5 mtl-1 supE44 leuB6 thi-1) and E. coli JM109 (recAl $\Delta l a c-$ pro endAl gyrA96 thi-1 hsdR17 supE44 relAI $\mathrm{F}^{\prime}$ traD36 proAB lacI ${ }^{9} Z$ $\triangle M 15$ ) were used as hosts for cloning and sequencing. Plasmid pBR322 and bacteriophages $M 13 \mathrm{mp} 18$ and $M 13 \mathrm{mp} 19$ were used as the vectors.

Media. E. coli strains harbouring plasmids were grown on LB broth or on M9CA medium (Maniatis et al., 1982), each of which contained $50 \mu \mathrm{g}$ ampicillin $\mathrm{ml}^{-1}$ (sodium salt, Sigma). $2 \times \mathrm{YT}$ broth was used for cultivation of $E$. coli JM109 infected with M13 bacteriophage (Messing, 1983). P-medium contained (w/v) 1.0\% Polypepton (Nihon Pharmaceutical), $0.5 \%$ yeast extract (Difco), $0.1 \% \mathrm{KH}_{2} \mathrm{PO}_{4}, 0.25 \%$ $\mathrm{Na}_{2} \mathrm{HPO}_{4} \cdot 12 \mathrm{H}_{2} \mathrm{O}$ and $0.02 \% \mathrm{MgSO}_{4} .7 \mathrm{H}_{2} \mathrm{O}$, and was used for the propagation of Bacillus sp. KSM-330. Solid media contained 0.8 or $1.5 \%(\mathrm{w} / \mathrm{v})$ Bacto agar (Difco).

Preparation of DNA. Bacillus sp. KSM-330 cells grown on P-medium at $30^{\circ} \mathrm{C}$ for $24 \mathrm{~h}$ were harvested by centrifugation $(9800 \mathrm{~g}, 10 \mathrm{~min})$ at $4{ }^{\circ} \mathrm{C}$. Genomic DNA was prepared from precipitated cells as described by Saito \& Miura (1963). Plasmid DNA and the replicative form of M13 bacteriophage DNA were isolated by the alkaline extraction procedure of Birnboim \& Doly (1979). Covalently closed circular DNA was purified by $\mathrm{CsCl} /$ ethidium bromide equilibrium density gradient centrifugation.

Cloning of the endoglucanase gene. Genomic DNA from Bacillus sp. KSM-330 and plasmid pBR322 DNA were both digested with HindIII (Boehringer Mannheim) and ligated with T4 DNA ligase (Boehringer Mannheim). The ligation mixture was used for transformation of competent $E$. coli HB101 cells (purchased from Takara Shuzo). Transformants that appeared on LB agar plates supplemented with ampicillin were overlaid with $1.0 \%(w / v)$ agar that contained $0.5 \%$ (w/v) CMC (degree of substitution 0.68, Sanyo Kokusaku Pulp), 1.0\% (w/v) NaCl, $0.1 \mathrm{mg}$ lysozyme $\mathrm{ml}^{-1}$ and $50 \mathrm{~mm}$-citric acid/sodium citrate buffer (pH 5.2). After incubation at $37^{\circ} \mathrm{C}$ for $5 \mathrm{~h}$, production of the endoglucanase activity by the transformants was detected by staining the overlaid CMC with Congo red dye, as described by Teather \& Wood (1982).

Assay of endoglucanase activity. E. coli carrying the recombinant plasmid was grown on $\mathrm{LB}$ broth supplemented with ampicillin at $37^{\circ} \mathrm{C}$ for $24 \mathrm{~h}$. Cells were harvested from $35 \mathrm{ml}$ of the culture by centrifugation $(9800 \mathrm{~g}, 10 \mathrm{~min})$ at $4{ }^{\circ} \mathrm{C}$ and were resuspended in $7 \mathrm{ml}$ $10 \mathrm{~mm}-\mathrm{MOPS} / \mathrm{NaOH}$ buffer ( $\mathrm{pH} \mathrm{7.0)}$ ). The suspension of cells was sonicated at $4{ }^{\circ} \mathrm{C}$, and the cell debris was removed by centrifugation $(12000 \mathrm{~g}, 15 \mathrm{~min})$ at $4^{\circ} \mathrm{C}$. The endoglucanase activity of the supernatant was assayed as described previously (Ozaki \& Ito, 1991). The preparation of enzyme was incubated at $40{ }^{\circ} \mathrm{C}$ for $60 \mathrm{~min}$ with $100 \mathrm{~mm}$-citrate buffer ( $\mathrm{pH} 5 \cdot 2$ ) that contained $1.0 \%(\mathrm{w} / \mathrm{v})$ CMC (degree of substitution 0.68 , Sanyo Kokusaku Pulp), and the amount of reducing sugar liberated was measured by the 3,5-dinitrosalicylic acid procedure (Miller et al., 1960). One unit (U) of enzymic activity was defined as the amount of enzyme that produced $1.0 \mu \mathrm{mol}$ of reducing sugar as glucose per minute under the conditions of the reaction.

Hybridization analysis of DNA digests. HindIII digests of Bacillus sp. KSM-330 genomic DNA $(5 \mu \mathrm{g})$ were subjected to electrophoresis on a $0.8 \%(w / v)$ agarose gel and then electrophoretically transferred to a Zeta-Probe blotting membrane (Bio-Rad) after denaturation by soaking the gel with $0.2 \mathrm{M}-\mathrm{NaOH} / 0.5 \mathrm{M}-\mathrm{NaCl}$ for $30 \mathrm{~min}$ at room temperature. Approximately $0.4 \mu \mathrm{g}$ of the HindIII insert, isolated from the recombinant plasmid, was labelled with digoxigenin-11-dUTP and used as a probe for hybridization analysis of the HindIII digests of the genomic DNA on the membrane, by use of a DNA-Labelling and Detection Kit (Boehringer Mannheim).

Nucleotide sequencing. Restriction fragments were subcloned into an appropriate position of the multiple cloning site of M13mp18 or M13mp19, and ordered deletion clones for sequencing were prepared by the method of Henikoff (1984), using a Kilo-Sequence Deletion Kit (Takara Shuzo). Single-stranded DNA was prepared by the procedure of Messing (1983). The nucleotide sequence was determined by the dideoxy chain-termination method of Sanger et al. (1977), using a fluorescent dye primer (Smith et al., 1986) and a modified T7 DNA polymerase (Sequenase, United States Biochemical), on an automated DNA sequencer (Applied Biosystems). Approximately 300 bases were read from a sample in each lane, and both strands of the endoglucanase gene were completely sequenced.

\section{Results and Discussion}

\section{Cloning of the gene for Endo-K}

Among several thousand ampicillin-resistant transformants of $E$. coli $\mathrm{HB101}$, one was found to produce endoglucanase activity, as detected by the procedure for staining with Congo red dye. This endoglucanaseexpressing transformant contained a $7.7 \mathrm{~kb}$ recombinant plasmid (pKC3301) carrying two HindIII inserts of $3 \cdot 1$ and $0.2 \mathrm{~kb}$ in the HindIII site of pBR322 (Fig. 1). E. coli HB101 harbouring pKC3301 produced intracellular endoglucanase activity at a rate of approximately $10 \mathrm{U}$ per litre of broth, when cells were grown at $37^{\circ} \mathrm{C}$ for $24 \mathrm{~h}$ on LB broth that contained ampicillin. The plasmidencoded endoglucanase was active from $\mathrm{pH} 4.2$ to 7.0 with a maximum activity at $\mathrm{pH} 5 \cdot 2$, and it was active from 10 to $60^{\circ} \mathrm{C}$ with a maximum activity at $45^{\circ} \mathrm{C}$ (data not shown). These characteristics of the activity correspond to those of the Endo-K secreted by Bacillus sp. KSM-330 (Ozaki \& Ito, 1991).

To clarify the origin of the $3.1 \mathrm{~kb}$ insert of pKC 3301, hybridization analysis was done using the digoxigeninlabelled $3 \cdot 1 \mathrm{~kb}$ insert of $\mathrm{pKC} 3301$ as a probe. The labelled insert of pKC3301 hybridized with a $3 \cdot 1 \mathrm{~kb}$ fragment in HindIII digests of the genomic DNA from Bacillus sp. KSM-330 blotted on a membrane (data not shown). Thus, the $3.1 \mathrm{~kb}$ HindIII insert in pKC3301 appeared to have been derived from the genomic DNA of Bacillus sp. KSM-330.

\section{Location of the gene for Endo-K}

The $3.1 \mathrm{~kb}$ insert isolated from pKC3301 was subcloned into the HindIII site of pBR322 using E. coli. $\mathrm{HB} 101$ as host strain. Two plasmids, pKC 330 and pKC330R, were obtained, carrying the insert in opposite orientations. The yields of Endo-K activity of $E$. coli HB101 that 


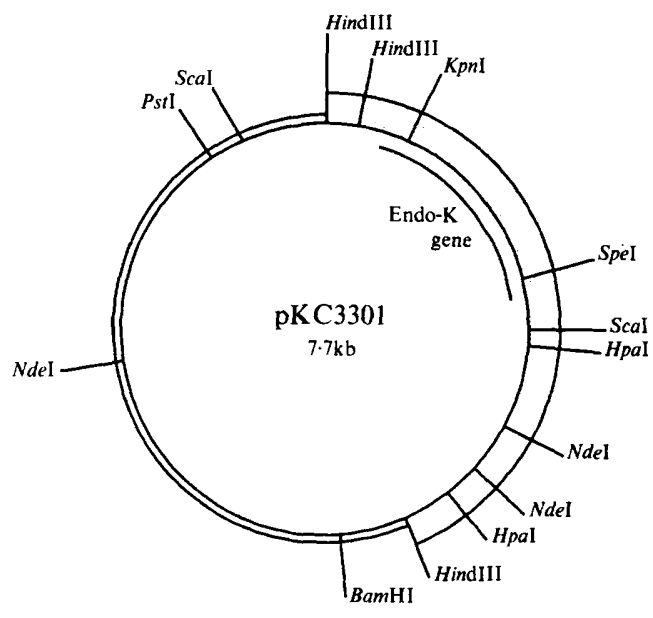

Fig. 1. Restriction map of plasmid pKC3301. The thick line indicates cloned HindIII fragments from genomic DNA of Bacillus sp. KSM330. The stippled area indicates a region that is essential for expression of endoglucanase activity.

Table 1. Endoglucanase activities isolated from $E$. coli $\mathrm{HB} 101$ cells carrying various plasmids

\begin{tabular}{lcc}
\hline Plasmid & $\begin{array}{c}\text { Growth } \\
\left(\text { OD }_{600}\right)\end{array}$ & $\begin{array}{c}\text { Activity } \\
\text { [U (1 culture) }\end{array}$ \\
\hline pKC3301 & $5 \cdot 1$ & 9.9 \\
pKC330 & 5.6 & 13.4 \\
pKC330R & 5.0 & $12 \cdot 1$ \\
pBR322 & 5.9 & 0 \\
\hline \hline
\end{tabular}

carried $\mathrm{pKC} 330$ and $\mathrm{pKC} 330 \mathrm{R}$ were almost the same as or slightly higher than that of E. coli HB101 (pKC3301), regardless of the orientation of the $3 \cdot 1 \mathrm{~kb}$ insert (Table 1 ). Thus, it was confirmed that the gene for Endo-K was included in the $3.1 \mathrm{~kb}$ insert and that the gene was probably expressed under the control of its own promoter in this insert. In addition, the enzyme activity was detected in the recombinant $E$. coli $\mathrm{HB} 101$, even when a $1.0 \mathrm{~kb} \mathrm{HpaI}$ fragment of the $3.1 \mathrm{~kb}$ insert was deleted from $\mathrm{pKC} 3301$ by subcloning. This observation suggested that the gene for Endo-K is located in a $1.8 \mathrm{~kb}$ HindIII-HpaI fragment, as shown by the stippled area in Fig. 1.

\section{Nucleotide sequence analysis}

The nucleotide sequence of the $1.8 \mathrm{~kb}$ HindIII-HpaI fragment was determined. Only one large open reading frame (ORF), beginning with an ATG codon at nucleotide 226 and ending with a TAA codon at nucleotide 1615 , was identified in the 1816 bp nucleotide sequence that was determined (Fig. 2). Upstream from this ORF, there is a putative ribosome-binding site with a sequence of AAGGGAGATGA, followed five bases later by a potential initiation codon, ATG. The sequence would exhibit a free energy of binding $(\Delta G)$ of -13.0 $\mathrm{kcal} \mathrm{mol}^{-1}\left(-54.6 \mathrm{~kJ} \mathrm{~mol}^{-1}\right)$, as calculated by the method of Tinoco et al. (1973), if it bound to the $3^{\prime}$ end of the 16S rRNA from $B$. subtilis. The $\Delta G$ value and the distance between the initiation codon and this putative ribosome-binding site agree reasonably well with data for other reported ribosome-binding sites from several strains of Bacillus (Hager \& Rabinowitz, 1985).

The region upstream from the ORF was scanned for sequences with homologies to various types of promoter consensus sequence recognized by RNA polymerases from $B$. subtilis (Doi \& Wang, 1986). The sequence from nucleotides 35 to 65 resembles the consensus sequence of the sigma A-type vegetative promoters of $B$. subtilis (Moran et al., 1982). This sequence consists of TAGAAA as the potential -35 region and TATATT as the potential -10 region, separated by 19 nucleotides. A sequence, resembling the consensus sequence of sigma C-type promoters of $B$. subtilis (Johnson et al., 1983), was found upstream from the putative ribosome-binding site of the gene from Bacillus sp. KSM-330. This sequence begins at nucleotide 181 ; it includes the potential -35 region of AAATT and the potential -10 region of AATTTATTTTA; and the two regions are separated by 14 nucleotides.

A large inverted-repeat sequence was found downstream from the termination codon of the ORF (from nucleotides 1691 to 1732). The $\Delta G$ value of this sequence for a stem-loop structure was calculated to be $-19.8 \mathrm{kcal}$ $\mathrm{mol}^{-1}\left(-82.9 \mathrm{~kJ} \mathrm{~mol}^{-1}\right)$, which could be sufficient for termination of transcription. However, there is neither a GC-rich segment in the stem nor a poly(T) segment downstream from the stem, both of which are considered to be characteristics of $\rho$-independent terminators of transcription in bacterial genes (Adhya \& Gottesman, 1978). Nevertheless, the combination of potential promoter and terminator sequences suggests that the gene for Endo-K may be monocistronic.

\section{Amino acid sequence analysis}

The ORF in the nucleotide sequence encoded 463 amino acid residues, as indicated under the nucleotide sequence in Fig. 2. The molecular mass of the unprocessed protein was calculated to be $51882 \mathrm{Da}$. There was a short, relatively basic, hydrophilic region, from amino acids 1 to 6 , followed by a hydrophobic region that extended from amino acids 7 through 30 . This hydrophilichydrophobic sequence resembles the signal peptide of extracellular proteins of Bacillus (Mézes \& Lampen, 1985). The deduced sequence from amino acids 56 to 75 is identical to the amino-terminal 20 amino acid residues 


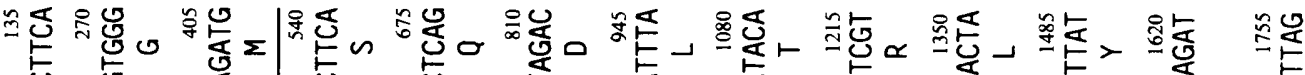

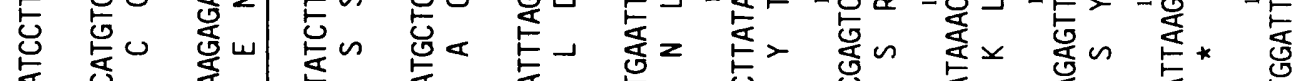

妾

复步

或

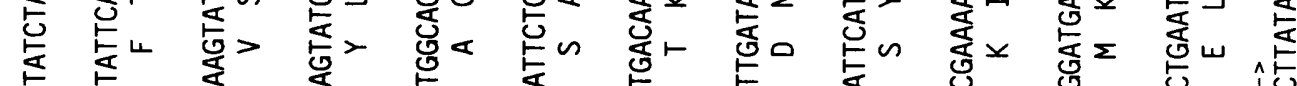

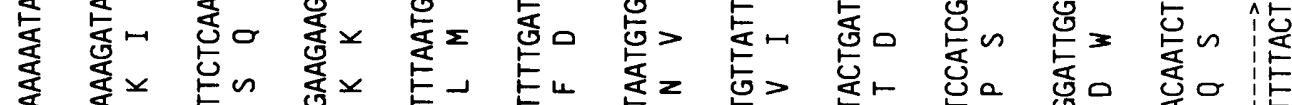

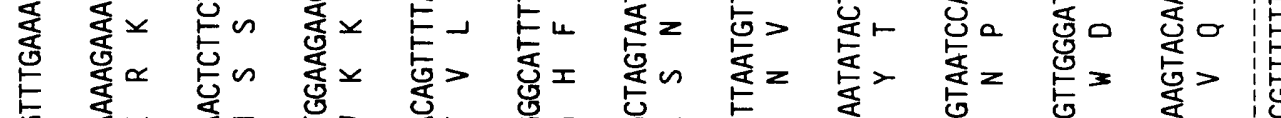

总 新

莺

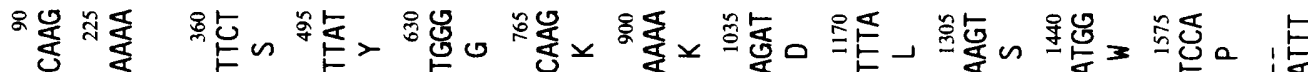

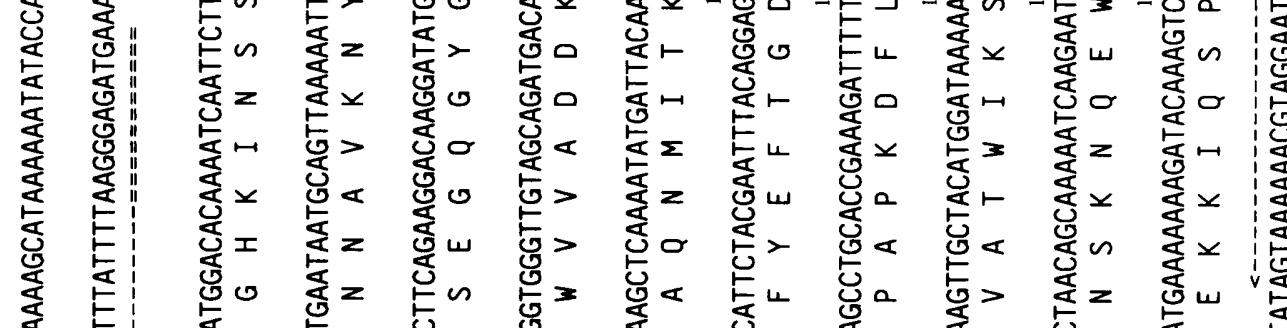

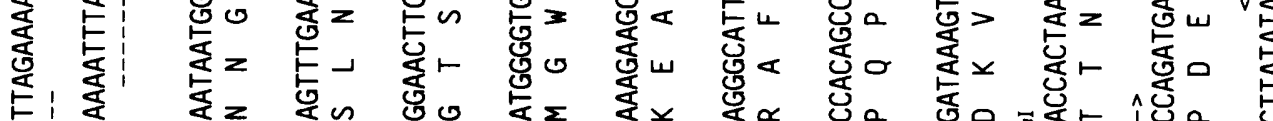

究

妾

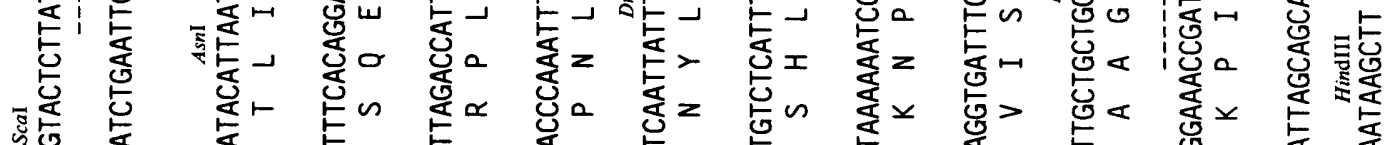

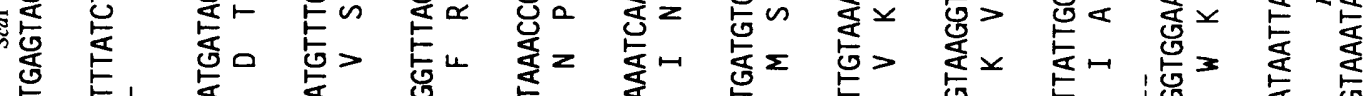

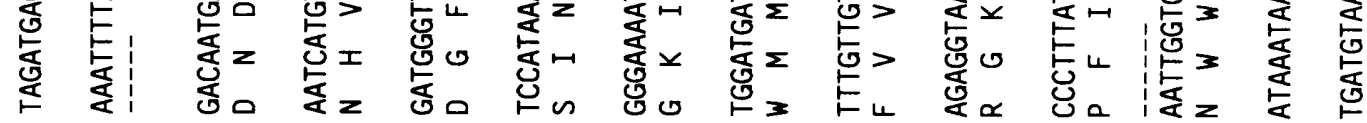

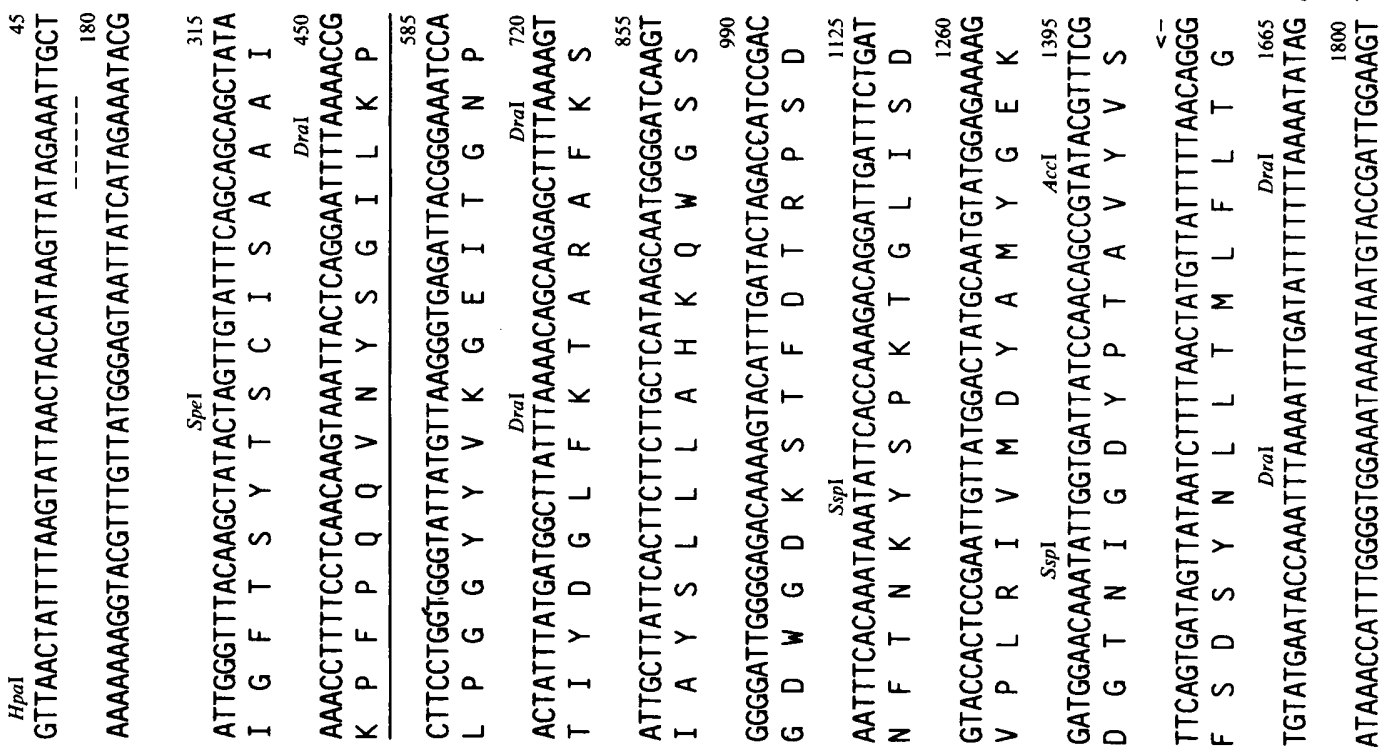

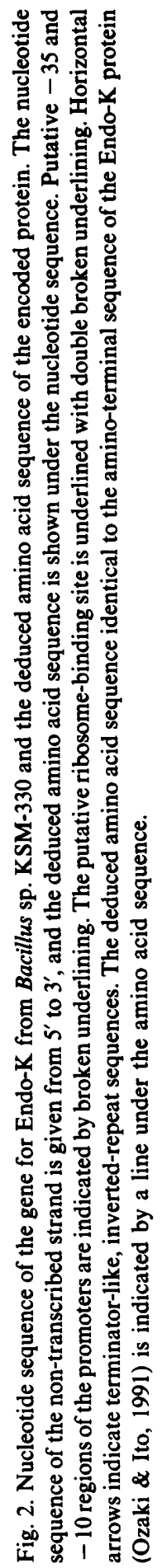


of the Endo-K protein secreted by Bacillus sp. KSM-330 (Ozaki \& Ito, 1991), and the sequence from amino acids 53 to 55 (Val-Ser-Ala) resembles the recognition site of signal peptidases (Perlman \& Halvorson, 1983). The Endo-K protein in Bacillus sp. KSM-330 may possibly be cleaved by a signal peptidase at the bond between Ala 55 and Val 56 during secretion across the cytoplasmic membrane. However, the site of cleavage is far from the carboxy-terminus of the hydrophobic region and the possible signal peptide of 55 amino acid residues seems somewhat longer than other reported signal peptides of endoglucanases from Bacillus (Fukumori et al., 1986a; MacKay et al., 1986; Robson \& Chambliss, 1987). The amino-terminus of Endo-K could, therefore, be processed after secretion by a proteolytic enzyme. The molecular mass of the mature enzyme was calculated to be $46090 \mathrm{Da}$, based upon the deduced amino acid sequence from amino acids 56 to 463 . This size is slightly larger than the $42 \mathrm{kDa}$ determined by SDS-PAGE of Endo-K that was purified from Bacillus sp. KSM-330 (Ozaki \& Ito, 1991), suggesting that the carboxy-terminal region of Endo-K may be subjected to proteolysis.

The endoglucanase activity of the purified Endo-K from Bacillus sp. KSM-330 is completely abolished by the presence of $N$-bromosuccinimide at low concentrations, and at least one Trp residue seems to be involved in the mechanism of action of this enzyme (Ozaki \& Ito, 1991). The titrated number of total Trp residues in the enzyme molecule, 11.4 , is very close to the number of Trp residues, 12 , deduced from the nucleotide sequence of the gene.

\section{Homology of the amino acid sequence with those of other} enzymes

The deduced amino acid sequence of the Endo-K protein was compared with those of enzymes, reported to date, from various strains of Bacillus (Fukumori et al., 1986a, b; MacKay et al., 1986; Nakamura et al., 1987; Robson \& Chambliss, 1987; Fukumori et al., 1989; Baird et al., 1990; Ozaki et al., 1990), Clostridium (Béguin et al., 1985; Grépinet \& Béguin, 1986; Joliff et al., 1986; Hall et al., 1988; Schwarz et al., 1988; Zappe et al., 1988; Faure et al., 1989; Jauris et al., 1990), Cellulomonas (Nakamura et al., 1986; Wong et al., 1986), Ruminococcus (Ohmiya et al., 1989; Poole et al., 1990; Wang \& Thomson, 1990), Butyrivibrio (Berger et al., 1989; Hazlewood et al., 1990), Pseudomonas (Hall \& Gilbert, 1988), Erwinia (Guiseppi et al., 1988), Streptomyces (Nakai et al., 1988) and Trichoderma (Penttilä et al., 1986; Saloheimo et al., 1988). The sequence from amino acids 56 to 443 of Endo-K exhibited $30 \%$ homology to that of the celA endoglucanase from Clostridium thermocellum NCIB10682 (Béguin et al., 1985). In addition, $25 \%$ homology in terms of

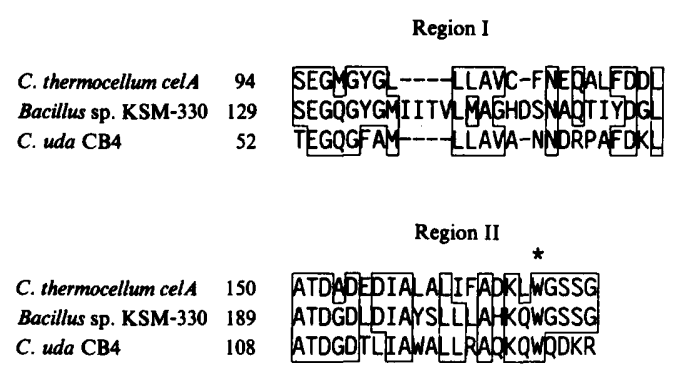

Fig. 3. Homology between the amino acid sequences of endoglucanases from Bacillus sp. KSM-330, C. thermocellum NCIB10682 (celA) and C. uda CB4.

amino acid sequence was observed between Endo-K (from amino acids 130 to 273) and the endoglucanase from Cellulomonas uda CB4 (Nakamura et al., 1986). No such homology was observed between Endo-K and other endoglucanases from Bacillus. This negative result suggests that the gene for Endo-K has evolved from a different ancestral gene than those for other reported enzymes from Bacillus. Henrissat et al. (1989) compared the amino acid sequences of cellulolytic enzymes from various origins by means of hydrophobic cluster analysis (Gaboriaud et al., 1987) and classified them into six families (family A through family F). According to their criteria, Endo-K seems to belong to family D, because the endoglucanases from $C$. thermocellum NCIB 10682 and Cellulomonas uda CB4 have been classified as belonging to this family. A number of genes for endoglucanases from Bacillus have been sequenced, and some of the proteins (Fukumori et al., 1986a, b; MacKay et al., 1986; Nakamura et al., 1987; Robson \& Chambliss, 1987) have been classified as members of family A, and others (Fukumori et al., 1989; Baird et al., 1990; Ozaki et al., 1990) appear to belong to the same family because they are similar to the enzymes in family A. Therefore, Endo-K is the first case of an enzyme from Bacillus that belongs to family D.

The amino acid sequences from amino acids 130 to 156 (region I) and from amino acids 189 to 207 (region II) of Endo-K appear to be well conserved when suitably aligned with sequences of endoglucanases in family $D$, as shown in Fig. 3. This result implies that some of the conserved amino acids may play important roles in the action of these endoglucanases. Among the conserved amino acids, the Trp residue found in region II was notable, in that at least one Trp residue has been proved to be involved in the mechanism of the action of Endo-K (Ozaki \& Ito, 1991). The celA endoglucanase has a carboxy-terminal domain that consists of a direct repeat of 23 amino acids (Béguin et al., 1985), as is conserved in other endoglucanases from C. thermocellum (Grépinet \& Béguin, 1986; Joliff et al., 1986; Hall et al., 1988). These domains are unnecessary for both the catalytic activity 
(Hall et al., 1988) and binding to cellulose (Durrant et al., 1991), and are separated from a catalytic domain by sequences which are rich in Pro, Thr and Ser residues. Such sequences of the reiterated amino acids and the Pro-Thr-Ser are absent in the Endo-K molecule, suggesting that this enzyme may be a single domain protein.

The aim of this study was to explain the difference in pH optima between the acid and alkaline endoglucanases of Bacillus. We expected that the acid endoglucanase, Endo-K, of Bacillus sp. KSM-330 would show some homology to the alkaline endoglucanase of Bacillus sp. KSM-635 (Ozaki et al., 1990) and to other alkaline and neutral endoglucanases of Bacillus reported to date (Fukumori et al., 1986a, b; MacKay et al., 1986; Nakamura et al., 1987; Robson \& Chambliss, 1987; Fukumori et al., 1989; Baird et al., 1990). Interestingly, Endo-K exhibits no homology to these alkaline or neutral enzymes. It is clear that at least one Trp residue is involved in an action of this acid endoglucanase and of the alkaline endoglucanase from Bacillus sp. KSM-635 (Ozaki et al., 1990; Yoshimatsu et al., 1990), regardless of the difference in $\mathrm{pH}$ optima. We are now attempting to identify the Trp residue(s) that is necessary for the action of acid and alkaline endoglucanases by site-directed mutagenesis.

\section{References}

AdHYA, S. \& GotTesman, M. (1978). Control of transcription termination. Annual Review of Biochemistry 47, 967-996.

AU, K.-S. \& ChaN, K.-Y. (1987). Purification and properties of the endo-1,4- $\beta$-glucanase from Bacillus subtilis. Journal of General Microbiology 133, 2155-2162.

Baird, S. D., Johnson, D. A. \& Seligy, V. L. (1990). Molecular cloning, expression, and characterization of endo- $\beta$-1,4-glucanase genes from Bacillus polymyxa and Bacillus circulans. Journal of Bacteriology 172, 1576-1586.

BÉGUIN, P., CORNET, P. \& AUBERT, J.-P. (1985). Sequence of a cellulase gene of the thermophilic bacterium Clostridium thermocellum. Journal of Bacteriology 162, 102-105.

Berger, E., Jones, W. A., Jones, D. T. \& WoOds, D. R. (1989). Cloning and sequencing of an endoglucanase (endI) gene from Butyrivibrio fibrisolvens H17c. Molecular and General Genetics 219. 193-198

BIRNBOIM, H. C. \& Doly, J. (1979). A rapid alkaline extraction procedure for screening recombinant plasmid DNA. Nucleic Acids Research 7, 1513-1523.

Dhillon, N., Chimber, S., SaXena, M., Pajni, S. \& Vadehra, D. V. (1985). A constitutive endoglucanase (CMCase) from Bacillus licheniformis-1. Biotechnology Letters 7, 695-697.

DoI, R. H. \& WANG, L.-F. (1986). Multiple procaryotic ribonucleic acid polymerase sigma factors. Microbiological Reviews 50, 227-243.

Durrant, A. J., Hall, J., Hazlewood, G. P. \& Gilbert, H. J. (1991). The non-catalytic $C$-terminal region of endoglucanase $E$ from Clostridium thermocellum contains a cellulose-binding domain. Biochemical Journal 273, 289-293.

Faure, E., Belaich, A., Bagnara, C., Gaudin, C. \& Belaich, J.-P. (1989). Sequence analysis of the Clostridium cellulolyticum endoglucanase-A-encoding gene, celCCA. Gene 84, 39-46.
FUKUmori, F., Kudo, T., NARAHAShI, Y. \& HoRIKOSHI, K. (1986a) Molecular cloning and nucleotide sequence of the alkaline cellulase gene from the alkalophilic Bacillus sp. strain 1139. Journal of General Microbiology 132, 2329-2335.

FuKUmori, F., SASHIHARA, N., KUdO, T. \& HoRIKoshi, K. (1986b). Nucleotide sequences of two cellulase genes from alkalophilic Bacillus sp. strain N-4 and their strong homology. Journal of Bacteriology 168, 479-485.

Fukumori, F., Kudo, T., Sashihara, N., Nagata, Y., Ito, K. \& HorIKosh, K. (1989). The third cellulase of alkalophilic Bacillus sp. strain N-4: evolutionary relationships within the cel gene family. Gene 76, 289-298.

Gaboriaud, C., Bissery, V., Benchetrit, T. \& Mornon, J. P. (1987). Hydrophobic cluster analysis: an efficient new way to compare and analyse amino acid sequences. FEBS Letters 224, 149-155.

GrÉPINET, O. \& BÉGUIN, P. (1986). Sequence of the cellulase gene of Clostridium thermocellum coding for endoglucanase B. Nucleic Acids Research 14, 1791-1799.

Guiseppi, A., Cami, B., Aymeric, J.-L., Ball, G. \& Creuzet, N. (1988). Homology between endoglucanase $Z$ of Erwinia chrysanthemi and endoglucanases of Bacillus subtilis and alkalophilic Bacillus. Molecular Microbiology 2, 159-164.

HAGER, P. W. \& RABINOWITZ, J. C. (1985). Translational specificity in Bacillus subtilis. In The Molecular Biology of the Bacilli, vol. II, pp. 132. Edited by D. A. Dubnau. Orlando: Academic Press.

Hall, J. \& Gilbert, H. J. (1988). The nucleotide sequence of a carboxymethyl-cellulase gene from Pseudomanas fuorescens subsp. cellulosa. Molecular and General Genetics 213, 112-117.

Hall, J., Hazlewood, G. P., Barker, P. J. \& Gilbert, H. J. (1988). Conserved reiterated domains in Clostridium thermocellum endoglucanases are not essential for catalytic activity. Gene 69, 29-38.

Hazlewood, G. P., Davidson, K., Laurie, J. I., Romaniec, M. P. M. \& GILBERT, H. J. (1990). Cloning and sequencing of the celA gene encoding endoglucanase A of Butyrivibrio fibrisolvens strain A46. Journal of General Microbiology 136, 2089-2097.

HENIKOFF, S. (1984). Unidirectional digestion with exonuclease III creates targeted breakpoints for DNA sequencing. Gene 28, 351-359.

Henrissat, B., Claeyssens, M., Tomme, P., Lemesle, L. \& Mornon, J.-P. (1989). Cellulase families revealed by hydrophobic cluster analysis. Gene 81, 83-95.

Jauris, S., Rücknagel, K. P., Schwarz, W. H., Kratzsch, P., Bronnenmeier, K. \& Staudenbauer, W. L. (1990). Sequence analysis of the Clostridium stercorarium celZ gene encoding a thermoactive cellulase (Avicelase I): identification of catalytic and cellulose-binding domains. Molecular and General Genetics 223, 258-267.

Johnson, W. C., Moran, C. P., JR. \& Losick, R. (1983). Two RNA polymerase sigma factors from Bacillus subtilis discriminate between overlapping promoters for a developmentally regulated gene. Nature, London 302, 800-804.

JolifF, G., BÉGUIN, P. \& AUBERT, J.-P. (1986). Nucleotide sequence of the cellulase gene celD encoding endoglucanase D of Clostridium thermocellum. Nucleic Acids Research 14, 8605-8613.

MacKay, R. M., Lo, A., Willick, G., Zuker, M., Baird, S., Dove, M., Moranelli, F. \& Seligy, V. (1986). Structure of a Bacillus subtilis endo- $\beta$-1,4-glucanase gene. Nucleic Acids Research 14, 91599170.

Maniatis, T., Fritsch, E. F. \& SAMbrook, J. (1982). Molecular Cloning: a Laboratory Manual. Cold Spring Harbor, NY: Cold Spring Harbor Laboratory.

Messing, J. (1983). New M13 vectors for cloning. Methods in Enzymology 101, 20-78.

MÉzes, P. S. F. \& LAMPEN, J. O. (1985). Secretion of proteins by bacilli. In The Molecular Biology of the Bacilli, vol. II, pp. 151-183. Edited by D. A. Dubnau. Orlando: Academic Press.

Miller, G. L., Blum, R., GlenNon, W. E. \& Burton, A. L. (1960). Measurement of carboxymethylcellulase activity. Analytical Biochemistry 2, 127-132.

Moran, C. P., Jr, Lang, N., LeGrice, S. F. J., Lee, G., Stephens, M., Sonenshein, A. L., Pero, J. \& Losick, R. (1982). Nucleotide sequences that signal the initiation of transcription and translation in Bacillus subtilis. Molecular and General Genetics 186, 339-346. 
NAKAI, R., HORINOUCHI, S. \& BEPPU, T. (1988). Cloning and nucleotide sequence of a cellulase gene, cas $A$, from an alkalophilic Streptomyces strain. Gene 65, 229-238.

Nakamura, K., Misawa, N. \& Kitamura, K. (1986). Sequence of a cellulase gene of Cellulomonas uda CB4. Journal of Biotechnology 4, 247-254.

NAKamURA, A., UozUmi, T. \& BePPU, T. (1987). Nucleotide sequence of a cellulase gene of Bacillus subtilis. European Journal of Biochemistry 164, 317-320.

OhmiYa, K., Kajino, T., Kato, A. \& Shimizu, S. (1989). Structure of a Ruminococcus albus endo-1,4- $\beta$-glucanase gene. Journal of Bacterio$\log y$ 171, 6771-6775.

Okoshi, H., Ozaki, K., Shikata, S., Oshino, K., Kawai, S. \& Ito, S. (1990). Purification and characterization of multiple carboxymethyl cellulases from Bacillus sp. KSM-522. Agricultural and Biological Chemistry 54, 83-89.

OZAKI, K. \& ITO, S. (1991). Purification and properties of an acid endo1,4- $\beta$-glucanase from Bacillus sp. KSM-330. Journal of General Microbiology 137, 41-48.

Ozaki, K., Shikata, S., KawaI, S., Ito, S. \& Oramoto, K. (1990). Molecular cloning and nucleotide sequence of a gene for alkaline cellulase from Bacillus sp. KSM-635. Journal of General Microbiology 136, 1327-1334.

Penttilä, M., Lehtovaara, P., Nevalainen, H., Bhikhabhai, R. \& KNOWLES, J. (1986). Homology between cellulase genes of Trichoderma reesei: complete nucleotide sequence of the endoglucanase I gene. Gene 45, 253-263.

Perlman, D. \& Halvorson, H. O. (1983). A putative signal peptidase recognition site and sequence in eukaryotic and prokaryotic signal peptides. Journal of Molecular Biology 167, 391-409.

Poole, D. M., Hazlewood, G. P., Laurie, J. I., Barker, P. J. \& GILBERT, H. J. (1990). Nucleotide sequence of the Ruminococcus albus SY3 endoglucanase genes celA and celB. Molecular and General Genetics 223, 217-223.

Robson, L. M. \& Chambliss, G. H. (1987). Endo- $\beta$-1,4-glucanase gene of Bacillus subtilis DLG. Journal of Bacteriology 169, 2017-2025.

SAITo, H. \& MrURA, K. (1963). Preparation of transforming deoxyribonucleic acid by phenol treatment. Biochimica et Biophysica Acta 72. 619-629.

Saloheimo, M., Lehtovaara, P., Penttilä, M., Teeri, T. T., Stählberg, J., Johansson, G., Pettersson, G., Claeyssens, M., TOMME, P. \& KNOWLES, J. K. C. (1988). EGIII, a new endoglucanase from Trichoderma reesei: the characterization of both gene and enzyme. Gene $63,11-21$.
SANGer, F., Nickien, S. \& Coulson, A. R. (1977). DNA sequencing with chain-terminating inhibitors. Proceedings of the National Academy of Sciences of the United States of America 74, 54635467.

Schwarz, W. H., Schimming, S., RÜcrnagel, K. P., Burgschwaiger, S., Kreil, G. \& Staudenbauer, W. L. (1988). Nucleotide sequence of the celC gene encoding endoglucanase $C$ of Clostridium thermocellum. Gene 63, 23-30.

Shikata, S., SaEki, K., Okoshi, H., Yoshimatsu, T., Ozaki, K., KAWAI, S. \& ITo, S. (1990). Alkaline cellulases for laundry detergents: production by alkalophilic strains of Bacillus and some properties of the crude enzymes. Agricultural and Biological Chemistry 54, 91-96.

Smith, L. M., Sanders, J. Z., Kaiser, R. J., Hughes, P., Dodd, C., Connell, C. R., HeIner, C., Kent, S. B. H. \& Hood, L. E. (1986). Fluorescence detection in automated DNA sequence analysis. Nature, London 321, 674-679.

TEATHER, R. M. \& Wood, P. J. (1982). Use of Congo redpolysaccharide interactions in enumeration and characterization of cellulolytic bacteria from the bovine rumen. Applied and Environmental Microbiology 43, 777-780.

Tewari, H. K. \& Chahal, D. S. (1977). Growth and cellulase formation by Bacillus sp. Indian Journal of Microbiology 17, 2326.

Tinoco, I., JR, Borer, P. N., Dengler, B., Levine, M. D., Uhlenbeck, O. C., Crothers, D. M. \& Gralla, J. (1973). Improved estimation of secondary structure in ribonucleic acids. Nature New Biology 246, 40-41.

WANG, W. \& Thomson, J. A. (1990). Nucleotide sequence of the celA gene encoding a cellodextrinase of Ruminococcus flavefaciens FD-1. Molecular and General Genetics 222, 265-269.

Wong, W. K. R., Gerhard, B., Guo, Z. M., Kilburn, D. G., ANTHONY, R., WARREN, J. \& MilleR, R. C., JR (1986). Characterization and structure of an endoglucanase gene cenA of Cellulomonas fimi. Gene 44, 315-324.

Yoshimatsu, T., Ozaki, K., Shikata, S., Ohta, Y., Koike, S., Kawai, S. \& ITO, S. (1990). Purification and characterization of alkaline endo-1,4- $\beta$-glucanases from alkalophilic Bacillus sp. KSM-635. Journal of General Microbiology 136, 1973-1979.

ZAPPE, H., JoNES, W. A., JoNES, D. T. \& WoOds, D. R. (1988). Structure of an endo- $\beta$-1,4-glucanase gene from Clostridium acetobutylicum P262 showing homology with endoglucanase genes from Bacillus spp. Applied and Environmental Microbiology 54, 1289-1292. 